\title{
Yield of essential oil and safrole content based on fresh and dry biomass of long pepper in the Brazilian Amazon
}

\author{
Jacson Rondinelli da Silva NEGREIROS ${ }^{*}$, Daniela Popim MIQUELONI ${ }^{1}$, \\ Cleísa Brasil da Cunha CARTAXO ${ }^{1}$ \\ 1 Empresa Brasileira de Pesquisa Agropecuária do Acre - Embrapa Acre, Rodovia BR-364, km 14, 69900-970, Rio Branco, AC, Brasil. \\ * Autor Correspondente: jacson.negreiros@embrapa.br
}

\begin{abstract}
Long pepper (Piper hispidinervum) is an Amazonian species of commercial interest due to the production of safrole. Drying long pepper biomass to extract safrole is a time consuming and costly process that can also result in the contamination of the material by microorganisms. The objective of this study was to analyze the yield of essential oil and safrole content of fresh and dried biomass of long pepper accessions maintained in the Active Germoplasm Bank of Embrapa Acre, in the state of Acre, Brazil, aiming at selecting genotypes with best performance on fresh biomass to recommend to the breeding program of the species. Yield of essential oil and safrole content were assessed in 15 long pepper accessions. The essential oil extraction was performed by hydrodistillation and analyzed by gas chromatography. A joint analysis of experiments was performed and the means of essential oil yield and safrole content for each biomass were compared by Student's t-test. There was variability in the essential oil yield and safrole content. There was no difference between the types of biomass for oil yield; however to the safrole content there was difference. Populations 9, 10, 12 and 15 had values of oil yield between 4.1 and 5.3\%, and safrole content between 87.2 and $94.3 \%$. The drying process does not interfere in oil productivity. These populations have potential for selection to the long pepper breeding program using oil extraction in the fresh biomass.
\end{abstract}

KEYWORDS: Piper hispidinervum, breeding program, oil extraction.

\section{Rendimento do óleo essencial e teor de safrol com base em biomassa fresca e seca de pimenta longa na Amazônia brasileira}

\begin{abstract}
RESUMO
A pimenta longa (Piper hispidinervum) é uma espécie amazônica de interesse comercial devido à produção de safrol. A secagem da biomassa para extraçáo do óleo essencial demanda tempo e acarreta custos, podendo também resultar em contaminaçáo do material por microorganismos. O objetivo deste estudo foi analisar o rendimento de óleo essencial e teor de safrol da biomassa verde e seca de acessos de pimenta longa mantida no Banco Ativo de Germoplasma da Embrapa Acre a fim de selecionar genótipos com melhor desempenho em biomassa verde para recomendação ao programa de melhoramento genético da espécie. O rendimento do óleo essencial e o teor de safrol foram avaliados em 15 acessos de pimenta longa. Foi realizada uma análise conjunta de experimentos e as médias do rendimento do óleo essencial e do teor de safrol para cada população foram comparadas pelo teste t de Student. Houve variabilidade do rendimento de óleo essencial e do teor de safrol. Não houve diferença entre os tipos de biomassa para o rendimento do óleo, já para o teor de safrol houve diferença. As populaçôes 9, 10, 12 e 15 mostraram valores de rendimento de óleo entre 4,1 e 5,3\%, e teor de safrol entre 87,2 e 94,3\%. O processo de secagem náo interfere na produtividade de óleo. Estas populaçôes têm potencial para seleção para o programa de melhoramento genético de pimenta longa por meio da extraçáo de óleo essencial da biomassa verde.
\end{abstract}

PALAVRAS-CHAVE: Piper hispidinervum, programa de melhoramento, extração de óleo. 


\section{INTRODUCTION}

The long pepper (Piper hispidinervum C.DC.), is an endemic Amazon species of high commercial interest due to its safrole production (Gottlieb et al. 1981; Andrade et al. 2009). This secondary compound is classified as a sesquiterpene produced by plant metabolism and used in the chemistry industry to obtain heliotropin and piperonil butoxid, used as fragrance fixers by the cosmetic industries, as synergic agent in bio insecticides and traditional popular use (Maia et al. 1987; Figueirêdo et al. 2004; Sauter et al. 2012). Safrole is considered one of the most used essential oils in the world (Bizzo et al. 2009) and its commercial demand has stimulated research on breeding of long pepper plants, with good yield of essential oil and high safrole content, above the level of $90 \%$ required by the industry (Maia et al. 1987; Bergo et al. 2002).

Long pepper is a predominantly alogamous species with high degree of heterozygosis, which directly influences the management and the domestication of the species (Wadt and Kageyama 2004). There is disagreement over chromosome number, however Nunes et al. (2007) states that this is a diploid species $(2 \mathrm{n}=24)$, expanding the group of species of the genus Piper with basic number $\mathrm{x}=12$. According to those authors, this group might be a primitive group from which the $\mathrm{x}=13$ lineage has evolved. There is evidence of genetic diversity associated with high levels of safrole in native long pepper populations in the Amazon region, with distinct groups within micro regions of Upper and Lower Acre (Wadt and Kageyama 2004; Andrade et al. 2009). Propagation of this perennial species occurs by seeds and cuttings and plants reach $1.60 \mathrm{~m}$ to $1.80 \mathrm{~m}$ height, with fast growing and harvesting cycle of one to two years, while maintaining oil yield over successive harvest, presenting high capacity of regrowth after cutting and contributing to the sustainability of this activity (Bergo et al. 2005).

Extraction of long pepper essential oil is done after drying the biomass. This process may change the content of volatile compounds, which are sensible to water loss, directly affecting yield and composition of the essential oil (Corrêa et al. 2004; Rahimmalek and Goli 2013). Standardizing the biomass drying process of long pepper under field conditions is difficult since the harvest season take place mainly towards the end of the rainy season (from March to April) in the Amazon region (Bergo et al. 2005; Negreiros and Miqueloni 2013b). Excessive air moisture during this period leads to biomass contamination by microorganisms and increasing labor demand to turn the biomass pile on a daily frequency during four to eight days to the drying process.
The objective of this study was to analyze the yield of essential oil and safrole content of fresh and dried biomass of long pepper accessions maintained in the Active Germoplasm Bank of Embrapa Acre, Brazil, aiming at selecting genotypes with best performance on fresh biomass to recommend to the breeding program of the species.

\section{MATERIALS AND METHODS}

The experiment was carried out at the experimental station of Embrapa Acre during 2010, after extraction of essential oil from fresh and dried biomass from 15 populations of long pepper. Samples were collected from the Active Germplasm Bank (AGB) and analyzed in the Laboratory of Essential Oils of Embrapa Acre, in Rio Branco, Acre state, Brazil. The city is located at 9 $9^{\circ} 58^{\prime} 22^{\prime \prime} \mathrm{S}, 67^{\circ} 48^{\prime} 40^{\prime \prime} \mathrm{W}$ (datum WGS 84) and altitude of $160 \mathrm{~m}$. The climate is classified as AWI (hot and humid), according to Köppen classification, with medium temperature of $27^{\circ} \mathrm{C}$, annual rainfall of $1,940 \mathrm{~mm}$ and $80 \%$ relative humidity. The soil of the experimental area was classified as an Ultisol (Embrapa 2006), with the following chemical characteristics at a depth of $0.0-0.2 \mathrm{~m}$ : $\mathrm{pH}\left(\mathrm{H}_{2} 0\right)$ : 4.5; $\mathrm{K}: 0.1 \mathrm{cmol}_{\mathrm{c}} \mathrm{kg}^{-1}$; Ca: $1.0 \mathrm{cmol}_{\mathrm{c}} \mathrm{kg}^{-1} ; \mathrm{Mg}: 0.3$ cmol ${ }_{\mathrm{c}} \mathrm{kg}^{-1}$; A1: $1.4 \mathrm{cmol}_{\mathrm{c}} \mathrm{kg}^{-1}$; organic matter: $14.0 \mathrm{~g} \mathrm{~kg}^{-1}$; cation-exchange capacity: $1.8 \mathrm{cmol} \mathrm{kg}^{-1}$; base saturation: $26 \%$; aluminum saturation: $22 \%$, and $P: 4.0 \mathrm{mg} \mathrm{kg}^{-1}$, and the following physical characteristics: sand: $610 \mathrm{~g} \mathrm{~kg}^{-1}$; silt: $310 \mathrm{~g} \mathrm{~kg}^{-1}$ and clay: $80 \mathrm{~g} \mathrm{~kg}^{-1}$.

Planting was conducted in the rainfall period, in a $2 \times 2$ $\mathrm{m}$ arrangement adopting the recommended treatment for this crop species, with three annual weedings, with two before cutting the above ground biomass, between March and April, and one after fertilization based on soil analysis, with annual dressing application of $2 \mathrm{~g}$ of $\mathrm{P}_{2} \mathrm{O}_{5}, 7 \mathrm{~g}$ of N and $12 \mathrm{~g}$ of $\mathrm{K}_{2} \mathrm{O}$ per plant during January (Bergo et al. 2002).

The experimental design was completely randomized, involving 15 populations with one replication per population. Each replication consisted of a plot with $8 \times 22 \mathrm{~m}$ and 30 plants in three rows, with two considered border rows and 10 central plants per plot considered for analysis, in a total of 15 plots and 150 individuals.

Open pollinated populations of long pepper (Piper hispidinervum C.DC., Piperaceae) were initially collected in 2000 in the Valley of Acre, in the eastern region of the Acre state, Brazil, and subsequently established in the Active Germplasm Bank (AGB) of Embrapa Acre. The selection of the population for this study was based on regional representation, with populations derived mainly from the micro region between Rio Branco and Brasiléia, and consisted of a minimum number of 30 individuals per population, and by values of essential oil yield and safrole content commercially 
satisfactory (above 90\%) compared to other populations of the AGB (2000 individuals within 43 populations) observed in previous studies.

For each of 10 individuals in a plot from each population, two samples of aboveground biomass containing leaves and thin branches were collected. One of the samples, corresponding to the fresh biomass, with a mean of $70 \%$ moisture was immediately taken to the lab and analyzed while the second sample was taken to a solar drier for a four to six days drying period, being revolved on a daily basis until reaching $10 \%$ of moisture (Bergo et al. 2002). Sample of fresh and dried biomass were analyzed for moisture and safrole content, and yield of essential oil.

Biomass's moisture content (\%) was determined in order to calculate yield in moisture free basis (MFB). This moisture content was based on the principle of the immiscibility of the solvent (toluene) and the water from fresh and dried biomass (Figueirêdo et al. 2004). Six grams of fresh biomass and 5 $\mathrm{g}$ of dry biomass were chopped and put, separately, inside a $250 \mathrm{ml}$ round bottom flask. The flasks were connected to a Dean-Strak apparatus combined with a reflux condenser. Then, $80 \mathrm{ml}$ of toluene were added through the top of the condenser, in order to allow the backflow to the flask, which was heated at $120^{\circ} \mathrm{C}$, and the water content extracted from the biomass was recorded.

Yield of the essential oil (\%) was calculated based on fresh and dry biomass in the moisture free basis (Santos et al. 2004). This method was used to determine the content of essential oil in MFB and the result was expressed in percentage, corresponding to volume/weight of the essential oil from the fresh and dry biomass. The results were obtained based on laboratory conditions.

For determination of safrole content (\%), the essential oil was extracted by the method of cohobation or recirculation of condensed water (Heath 1977). Extraction was based on $90 \mathrm{~g}$ of fresh biomass and $35 \mathrm{~g}$ of dried biomass, for each individual from the 15 populations. The samples were mixed with $450 \mathrm{ml}$ of distillated water and subjected to the water boiling temperature in a heating mantle for $60 \mathrm{~min}$ for the dried biomass and $180 \mathrm{~min}$ for the fresh biomass. At the end of this period, the oil was collected and quantified in a gas cromatograph (6890, HP, Palo Alto, CA, USA) using Helium as the carrier gas and equipped with a flame ionization detector and capillary column of $30 \mathrm{~m}$ length and $25 \mathrm{~mm}$ internal diameter. The internal injector and detector were maintained at $250^{\circ} \mathrm{C}$ with reduced injection volume (split of approximately $1: 100$ ). The initial oven temperature was maintained at $80^{\circ} \mathrm{C}$ for $10 \mathrm{~min}$ with increment of $4{ }^{\circ} \mathrm{C}$ per minute to $140{ }^{\circ} \mathrm{C}$ with subsequent increase of $20^{\circ} \mathrm{C}$ per minute until the maximum temperature setting of $260^{\circ} \mathrm{C}$ (Figueiredo et al. 2004).
The variables essential oil yield (in MFB) and safrole content obtained for each of the 10 individuals per population were submitted to analysis of variance (ANOVA), considering each population as the treatment in separated analyzes. After that, when the ratio maximum to minimum experimental error mean square was less than seven (i.e. $\left.\mathrm{MSE}_{\max } / \mathrm{MSE}_{\min } \leq 7.0\right)$ a joint analysis of experiments was performed (Pimentel Gomes 1987, Neves et al. 2006). The means for type of biomass (fresh and dried) of each population were compared by Student's t-test, at $5 \%$ of probability. The analyzes were performed using Sisvar 5.3 (Ferreira 2008).

\section{RESULTS}

For oil yield the ratio of the maximum to minimum experimental error mean square was 6.27 , whereas, for the safrole content the $\mathrm{MSE}_{\max } / \mathrm{MSE}_{\text {min }}$ ratio was 7.45. Thus, it was only possible to make comparison for essential oil yield among populations. Populations 12, 2, 10, 1 and 11 were not different of populations 9, 15 and 13, but differed from the remaining populations in fresh biomass. For dry biomass populations 14, 11 and 9 differed only population $1,8,5$ and 4 (Table 1).

Table 1. Means of fifteen populations ( \pm standard deviation) of long pepper for essential oil yield based on the condition of analyzed biomass (fresh or dried), Rio Branco, Acre, Brazil.

\begin{tabular}{|c|c|c|c|c|c|c|c|c|}
\hline \multirow{3}{*}{$\begin{array}{l}\text { Population } \\
1\end{array}$} & \multicolumn{4}{|c|}{ Fresh Biomass } & \multicolumn{4}{|c|}{ Dried Biomass } \\
\hline & \multicolumn{4}{|c|}{ Yield (\%) } & \multicolumn{4}{|c|}{ Yield (\%) } \\
\hline & 4.28 & $( \pm 1.19)$ & A & $b$ & 3.19 & $( \pm 0.35)$ & $B$ & cde \\
\hline 2 & 4.85 & $( \pm 1.31)$ & A & $a b$ & 3.79 & $( \pm 0.97)$ & B & $a b c d$ \\
\hline 3 & 2.69 & $( \pm 0.57)$ & B & de & 3.99 & $( \pm 0.82)$ & A & $a b c$ \\
\hline 4 & 2.61 & $( \pm 0.58)$ & A & de & 2.62 & $( \pm 0.57)$ & A & $\mathrm{e}$ \\
\hline 5 & 2.61 & $( \pm 0.54)$ & A & de & 3.11 & $( \pm 0.57)$ & A & de \\
\hline 6 & 2.70 & $( \pm 0.72)$ & B & de & 3.99 & $( \pm 0.55)$ & A & $a b c$ \\
\hline 7 & 2.26 & $( \pm 0.30)$ & B & $\mathrm{e}$ & 3.69 & $( \pm 0.58)$ & $A$ & $a b c d$ \\
\hline 8 & 1.88 & $( \pm 1.26)$ & B & e & 3.38 & $( \pm 0.75)$ & A & cde \\
\hline 9 & 4.23 & $( \pm 0.77)$ & $A$ & $\mathrm{bc}$ & 4.33 & $( \pm 0.73)$ & A & $a b$ \\
\hline 10 & 4.62 & $( \pm 1.13)$ & A & $a b$ & 3.74 & $( \pm 0.71)$ & B & $a b c d$ \\
\hline 11 & 4.44 & $( \pm 0.85)$ & A & $\mathrm{b}$ & 4.28 & $( \pm 0.64)$ & A & $a b$ \\
\hline 12 & 5.34 & $( \pm 0.92)$ & A & a & 3.90 & $( \pm 0.87)$ & B & $a b c d$ \\
\hline 13 & 4.14 & $( \pm 0.69)$ & A & bc & 3.50 & $( \pm 1.00)$ & A & bcd \\
\hline 14 & 3.39 & $( \pm 0.61)$ & B & $\mathrm{cd}$ & 4.39 & $( \pm 0.92)$ & A & a \\
\hline 15 & 4.10 & $( \pm 1.05)$ & A & bc & 3.79 & $( \pm 0.97)$ & A & $a b c d$ \\
\hline General mean & 3.61 & & & & 3.71 & & & \\
\hline CV\% & 29.74 & & & & 13.18 & & & \\
\hline
\end{tabular}

* means followed by the same letter (uppercase in lines and lowercase in columns) are not significant different at the $5 \%$ level, using the Student's t-test. 
Populations 4, 5, 9, 11, 13 and 15 showed no difference in essential oil yield in relation to the type of biomass. Populations 1, 2, 10 and 12 showed higher yield of essential oil on fresh biomass. All of these populations, except for populations 4 and 5, showed yields above $4 \%$, which is considered satisfactory for the industry. The remaining populations showed better performance on dried biomass, with values of yield on fresh biomass below $3.4 \%$. For dried biomass, populations 14, 9 and 11 showed yields above 4\%, with lower variation than on fresh biomass (CV of $13.18 \%$ for dried biomass and $29.74 \%$ for fresh biomass), indicating a more homogeneous material after drying.

For content of safrole, populations 5, 8, 9, 10, 12 and 15 showed no difference on type of biomass (Table 2). These populations, except population 14, had safrole content values above $87 \%$, considered satisfactory for the industry. For dry biomass, only population 1 showed value below $80 \%$. The variation on this type of biomass was also lower than on fresh biomass (CV $4.53 \%$ and $8.18 \%$, respectively).

Populations 5, 9, 10, 12 and 15 showed no differences between types of biomass for both characteristics, essential oil yield and safrole content, and these populations, except 5 , were the ones that showed higher performance for all characteristics, according to the values required by industry especially for safrole content, based on fresh biomass.

Table 2. Means of fifteen populations ( \pm standard deviation) of long pepper for safrole content based on the condition of analyzed biomass (fresh or dried), Rio Branco, Acre, Brazil.

\begin{tabular}{|c|c|c|c|c|c|c|}
\hline \multirow{2}{*}{$\begin{array}{l}\text { Population } \\
1\end{array}$} & \multicolumn{3}{|c|}{ Fresh Biomass } & \multicolumn{3}{|c|}{$\begin{array}{c}\text { Dried Biomass } \\
\text { Safrole content }(\%)^{1}\end{array}$} \\
\hline & 69.44 & $( \pm 6.01)$ & $B$ & 77.42 & $( \pm 6.92)$ & A \\
\hline 2 & 83.51 & $( \pm 3.86)$ & B & 93.16 & $( \pm 2.18)$ & A \\
\hline 3 & 77.05 & $( \pm 4.29)$ & B & 93.66 & $( \pm 1.67)$ & A \\
\hline 4 & 71.54 & $( \pm 6.37)$ & B & 89.19 & $( \pm 1.85)$ & A \\
\hline 5 & 88.21 & $( \pm 4.21)$ & A & 91.26 & $( \pm 3.21)$ & A \\
\hline 6 & 82.25 & $( \pm 4.29)$ & B & 90.61 & $( \pm 2.99)$ & A \\
\hline 7 & 83.69 & $( \pm 3.09)$ & B & 94.03 & $( \pm 1.33)$ & A \\
\hline 8 & 88.34 & $( \pm 4.81)$ & A & 87.95 & $( \pm 4.28)$ & A \\
\hline 9 & 94.93 & $( \pm 3.97)$ & A & 91.30 & $( \pm 1.69)$ & A \\
\hline 10 & 87.16 & $( \pm 4.85)$ & A & 90.78 & $( \pm 4.35)$ & A \\
\hline 11 & 85.26 & $( \pm 4.72)$ & B & 93.65 & $( \pm 2.54)$ & A \\
\hline 12 & 89.80 & $( \pm 6.65)$ & A & 92.26 & $( \pm 6.35)$ & A \\
\hline 13 & 83.48 & $( \pm 5.54)$ & B & 92.84 & $( \pm 1.99)$ & A \\
\hline 14 & 87.75 & $( \pm 5.21)$ & B & 92.66 & $( \pm 1.25)$ & A \\
\hline 15 & 89.46 & $( \pm 5.28)$ & A & 93.16 & $( \pm 2.18)$ & A \\
\hline General mean & 84.12 & & & 90.93 & & \\
\hline CV\% & 8.19 & & & 4.53 & & \\
\hline
\end{tabular}

*means followed by the same letter in lines are not significant different at the $5 \%$ level, using the Student's t-test.

$1 \%$ of safrole content based on the totality of the essential oil extracted from the biomass. Other compounds which comprise the essential oil with levels of 5 to $1 \%$ are mainly terpinolene, biciclogermacrene and (E)- $\beta$-ocimene.

\section{DISCUSSION}

The influence of the drying process on yield and composition of the essential oil has been observed on several species, generally increasing yield and major component content (Corrêa et al. 2004; Sellami et al. 2011; Rahimmalek and Goli 2013). The variability of essential oil yield of long pepper populations (Table 1) is high, which indicates the possibility of genetic gains, as noted by Negreiros and Miqueloni (2013a) for long pepper. On the other hand, safrole content shows a higher degree of homogeneity. This variability was observed by Gottlieb et al. (1981), Bergo et al. (2005) and Estrela et al. (2006), who reported 3 to 5\% of oil yield on dried biomass of long pepper and 80 to $90 \%$ of safrole content in the individuals from the Amazon region and Andrade et al. (2009) observed oil yield of $0.9 \%$ and safrole content of $18.4 \%$ in Mato Grosso state, Brazil.

As expected, the values of essential oil yield and, specially, safrole content are higher in extractions on dried biomass compared to fresh biomass. In some populations of long pepper, safrole did not suffer significant reductions in essential oil on fresh biomass when compared to dry biomass. This indicates that, in some genotypes, the main composition of the essential oil is not influenced by the drying step used for extraction. This trend has already been observed in Piper aduncum by Negreiros and Miqueloni (2013b) in germoplasms from the Western Amazon.

This differential response is attributed to the loss of minor volatile compounds during the drying of the aboveground biomass, thus increasing the concentration of the major oil component (Smith and Kassim 1979; Santos et al. 2013). Azian et al. (2004) observed that the drying of Zingiber officinale before extraction of the essential oil promoted the rupture of parenchyma's cell walls, facilitating the release of the oil and the oil resin in the adjacent tissues thus, increasing the yield. Oil yield is also influenced by the amount of biomass used for extraction, resulting in a more efficient moisture removal when working with smaller quantities of biomass. Braga et al. (2005), in studies with long pepper, observed yields of 0.2 to $1.3 \%$ on fresh biomass while these values practically double on dry biomass.

However, in this study some populations showed higher values for extraction on fresh biomass (Table 1), which can be mainly attributed to the genetic constitution of the germoplasm, which probably has a lower content of volatile compounds. The content of major component, safrole, was not affected by the drying process (Table 2). Rohloff et al. (2005) also observed that the drying process has little influence on the oil peppermint (Mentha $\mathrm{x}$ piperita L.), which allow the elimination of the drying process, thus reducing costs for obtaining the essential oil. 
Increasing the moisture content leads to the opposite effect by reducing the safrole content, possibly due to the maintenance of volatile compounds in the essential oil (Smith and Kassim 1979; Braga et al. 2005; Costa et al. 2013). This effect is probably due to the maximum gene expression in the fresh biomass and the reduced the variability of individuals in dry biomass, since there was no standardization of plant material by the drying process. Arrigoni-Blank et al. (2010) also observed that there are no differences in yield and content of the major compound of the essential oil predominant on Hyptis pectinata, between dried or fresh biomass samples, also suggesting the influence of the genetic material.

Each genotype responds in a different way to environmental conditions and to the drying process, which removes the water by increasing the percentage of active principles in relation to plant weight (Arrigoni-Blank et al. 2010; Santos et al. 2013). In some herbs, many compounds of interest are lost during drying, due to high humidity, especially in the oil glands of leaves which are dried and the essential oil is carried out by diffusion of the moisture, causing loss of aromatic compounds (Martinazzo et al. 2010).

In addition to that, in the Amazon region, the harvest period of long pepper (towards the end of the rainy season) creates favorable conditions for contamination by microorganisms of the biomass used for extraction of essential oil due to the high air humidity, characteristic of the season. It also results in higher labor costs and resources employed in this step of the extraction process.

These results indicate that some populations of long pepper have good potential for extraction of essential oil with no need of biomass drying, as they suggest that there are no differences on yield of essential oil and safrole content in these populations, when extracted from fresh or dried biomass. Yield of essential oil was higher on dried biomass, however the values of yields obtained on fresh biomass were above $4 \%$, minimum required by the industry to be considered feasible for processing. Populations 9, 10, 12 and 15 showed satisfactory values, for oil yield and safrole content, indicating that the drying process is not indispensable for the extraction of essential oil from these populations.

\section{CONCLUSIONS}

Safrole content and essential oil yeld did not vary between fresh and dried aboveground biomass for populations 9, 10, 12 and 15. These populations showed potential for use in the long pepper breeding program aiming at the extraction of essential oil from fresh biomass.

\section{ACKNOWLEDGEMENTS}

To the Brazilian National Treasury for the financial support.

\section{REFERENCES}

Andrade, E.H. de A; Guimarães E.F.; Maia JGS. 2009. Variabilidade química em óleos essenciais de espécies de Piper da Amazônia, FEQ/UFPA, Belém. 448p.

Arrigoni-Blank, M.F.; Blank, A.F.; Costa, A.G.; Alves, P.B.; Costa, A.S. 2010. Influência do horário de colheita e de secagem no óleo essencial de Hyptis pectinata L. Poit (Lamiaceae). Scientia Plena, 6: 1-5.

Azian, M.N; Kamal, A.A.M.; Azlina, M.N. 2004. Changes of cell tructure in ginger during processing. Journal of Food Engineering, 62: 359-364.

Bergo, C.L.; Sá, C.P.; Pimentel, F.A.; Mendonça, H.A.; Souza, J.A.; Wadt, L.H.O.; Thomazini, M.J.; Cavalcante, M.J.B. 2002. Cultivo da pimenta longa (Piper hispidinervum) na Amazônia Ocidental [Embrapa Acre. Sistemas de Produção, 1], Embrapa Acre, Rio Branco. 29p.

Bergo, C.L; Mendonça, H.A.; Silva, M.R. 2005. Efeito da época e freqüência de corte de pimenta longa (Piper hispidinervum C. DC.) no rendimento de óleo essencial. Acta Amazonica, 35: 111-117.

Bizzo, H.R.; Hovell, A.M.C.; Rezende, C.M. 2009. Brazilian essential oils: general view, developments and perspectives. Quimica Nova, 32: 588-594.

Braga, N.P.; Cremasco, M.A.; Valle, R.C.C.R. 2005. The effects of fixed-bed drying on the yield and composition of essential oil from long pepper (Piper hispidinervum C. DC) leaves. Brazilian Journal of Chemical Engineering, 22: 257-262.

Corrêa, R.M.; Bertolucci, S.K.V.; Pinto, J.E.B.P.; Reis, E.S.; Alves, T.L. 2004. Rendimento de oleo essencial e caracterização organoléptica de folhas de assa-peixe submetidas a diferentes métodos de secagem. Ciência e Agrotecnologia, 28: 339-344.

Costa, G.A.; Carvalho Filho, J.L.S.; Deschamps, C. 2013. Rendimento e composição do óleo essencial de patchouli (Pogostemon cablin) conforme o tempo de extração. Revista Brasileiras de Plantas Medicinais, 15: 319-324.

Embrapa - Empresa Brasileira de Pesquisa Agropecuária. 2006. Centro Nacional de Pesquisa de Solos. Sistema Brasileiro de Classificaçáo de Solos. 2nd ed. EMBRAPA, Rio de Janeiro. 306p.

Estrela, L.L.V.; Fazolin, M.; Catani, V.; Alécio, M.R.; Lima, M.S. de. 2006. Toxicidade de óleos essenciais de Piper aduncum e Piper hispidinervum em Sitophilus zeamais. Pesquisa Agropecuária Brasileira, 41: 217-222.

Ferreira, D.F. 2008. Sisvar: um programa para análise e ensino de estatística. Symposium, 6: 36-41.

Ferreira, P.V. 1991. Estatística experimental aplicada à agronomia. EDUFAL, Maceió. 437p.

Figueirêdo, F.J.C.; Alves, S.M.; Santos, A.S.; Rocha Neto, O.G.R. 2004. Rendimento e qualidade fisico-quimica de óleo essencial extraído de diferentes composiçōes da biomassa área de pimenta longa. [Embrapa Amazônia Oriental. Boletim de Pesquisa e Desenvolvimento, 33], Embrapa Amazônia Oriental, Belém. 31p.

Gottlieb, O.R.; Koketsu, M.; Magalhães, M.T.; Maia, J.G.S.; Mendes, P.H.; Rocha, A.I.; Silva, M.L.; Wilberg, V.C. 1981. Óleos essenciais da Amazônia VII. Acta Amazonica, 11: 143-148. 
Heath, H.B. 1977. Flavorings, condiments and relishes. In: Desrosier, N.W. (Ed.) Elements of Food Technology. The Avipublishing Company, Westport, US. p. 666-701.

Maia, J.G.S.; Silva, M.L.; Luz, A.I.R.; Zoghbi, M.G.B.; Ramos, L.S. 1987. Espécies de Piper da Amazônia ricas em safrol. Química Nova, 10: 200-204.

Martinazzo, A.P.; Melo, E.C.; Correa, P.C.; Santos, R.H.S. 2010. Modelagem matemática e parâmetros qualitativos da secagem de folhas de capim-limão [Cymbopogon citratus (DC.) Stapf]. Revista Brasileira de Plantas Medicinais, 12: 488-498.

Negreiros, J.R. da S.; Miqueloni, D.P. 2013a. Divergência genética de populações de Piper hispidinervum C. DC. com base em caracteres morfoagronômicos. Pesquisa Agropecuária Tropical, 43: 209-217.

Negreiros, J.R. da S.; Miqueloni, D.P. 2013b. Teor de dilapiol em função do tipo de biomassa aérea em populaçóes de Piper aduncum. Revista de Ciências Agrarias, 56: 73-79.

Neves, T. dos S.; Carpanezzi, A.A.; Zuffellato-Ribas, K.C.; Marenco, R.A. 2006. Enraizamento de corticeira-da-serra em função do tipo de estaca e variações sazonais. Pesquisa Agropecuária Brasileira, 41: 1699-1705.

Nunes, J.D.; Torres, G.A.; Davide, L.C.; Salgado, C.C. 2007. Citogenética de Piper hispidinervum e Piper aduncum. Pesquisa Agropecuária Brasileira, 42: 1049-1052.

Pimentel Gomes, F. 1987. Curso de estatística experimental. 12th ed. Esalq, Piracicaba. 467p.

Rahimmalek, M.; Goli, S.A.H. 2013. Evaluation of six drying treatments with respect to essential oil yield, composition and color characteristics of Thymys daenensis subsp. daenensis. Celakleaves. Industrial Crops and Products, 42: 613-619.
Rohloff, J.; Dragland, S.; Mordal, R.; Iversen, T.H. 2005. Effect of harvest time and drying method on biomass production, essential oil yield, and quality of peppermint (Mentha x piperita L.). Journal of Agricultural and Food Chemistry, 53:4143-4248.

Santos, A.S.; Alves, S.M., Figueirêdo, F.J.C.; Rocha Neto, O.G. 2004. Descrição de sistema e de métodos de extração de óleos essenciais e determinação de umidade de biomassa em laboratório. [Embrapa Amazônia Oriental. Comunicado Técnico, 99], Embrapa Amazônia Oriental, Belém. 6p.

Santos, G.A. dos; Brenzan, M.A.; Serra, L.Z. 2013. Influência do cultivo na produção de biomassa, teor e composição do óleo essencial de Mentha spicata. Revista de Saúde e Biologia, 8:19-25.

Sauter, I.P.; Rossa, G.E.; Lucas, A.M.; Cibulski, S.P.; Roehe, P.M.; Silva, L.A.A.; Rott, M.B.; Vargas, R.M.F.; Cassel, E.; Poser, G.L. 2012. Chemical composition and amoebicidal activity of Piper hispidinervum (Piperaceae) essential oil. Industrial Crops and Products, 40: 292-295.

Sellami, I.H.; Wannes, W.A.; Bettaieb, I.; Berrima, S.; Chahed, T.; Marzouk, B.; Limam, F. 2011. Qualitative and quantitative changes in the essential oil of Laurus nobilis L. leaves as affected by different drying methods. Food Chemistry, 126: 691-697.

Smith, R. M.; Kassim, H. 1979. The essencial oil of Piper aduncum from Fiji. New Zealand Journal of Sciense, 22: 127-128.

Wadt, L.H.O.; Kageyama, P.Y. 2004. Estrutura genética e sistema de acasalamento de Piper hispidinervum. Pesquisa Agropecuária Brasileira, 39: 151-157.

Recebido em 25/02/2014

Aceito em 30/05/2014 